\title{
Influence of pruning on fruits production of jujube Ziziphus mauritiana Lam
}

\author{
Abdul Qadir Gola ${ }^{1 *}$, Muhammad Iqbal Jakhro², Asif khan Tareen ${ }^{3}$, \\ Mohammad Saleem Mastoi ${ }^{4}$ and Muzamil Ahmed Khosa ${ }^{5}$ \\ 1. Department of Horticulture, Sindh Agriculture University Tandojam, 70060-Pakistan \\ 2. PARC, Balochistan Agriculture Research and Development Center Quetta-Pakistan \\ 3. Department of Entomology, Sindh Agriculture University Tandojam, 70060- Pakistan \\ 4. Department of Agronomy, Sindh Agriculture University Tandojam, 70060-Pakistan \\ 5. Department of Education Extension, Sindh Agriculture University Tandojam, 70060-Pakistan \\ *Corresponding author's email: abdulqadiragri@gmail.com \\ Citation
}

Abdul Qadir Gola, Muhammad Iqbal Jakhro, Asif khan Tareen, Mohammad Saleem Mastoi and Muzamil Ahmed Khosa. Influence of pruning on fruits production of jujube Ziziphus mauritiana Lam. Pure and Applied Biology. Vol. 7, Issue 4, pp 1261-1267. http://dx.doi.org/10.19045/bspab.2018.700146

\begin{tabular}{llll}
\hline \hline Received: 03/05/2018 & Revised: 29/08/2018 & Accepted: 03/09/2018 & Online First: 06/09/2018 \\
\hline
\end{tabular}

Abstract

This study was conducted at Horticultural Research Institute, at the Sindh Agriculture University Tandojam, during the period of (March 2014) the influence of pruning on fruits production of jujube. The experiment was the laid out in (RCBD) with the four replications. Hence there were total 20 plants. Four treatments were too applied T1 (pruning on $20^{\text {th }}$ May) T2 (pruning on $25^{\text {th }}$ May) T3 (pruning on $15^{\text {th }}$ June) T4 (pruning on $25^{\text {th }}$ June) and the maximum number of branch per tree ( 25 days to flowering) and (65 days blooming on $15^{\text {th }}$ August to $25^{\text {th }}$ on September) and the fruit weight $(31.45 \mathrm{~g})$ the maximum fruit size $(30.50 \mathrm{~mm} 2)$ highest sugar $(6.22 \%)$ and the maximum vitamin-C contents on (130.50) Pruning in ber is required right from the year of planting. During the pre-bearing stage, it is done to build strong framework to bear the load and fruits. Pruning in Pakistan is to specific geographical location, in sub-tropical regions. It is done (15 ${ }^{\text {th }}$ May) is most suitable pruning time to maximum fruits yield and quality in ber. The depending upon latitude while in tropical regions, depending upon the possibility of winter rainfall. In Northern Sindh like in Hyderabad, Khairpure Lahore, Faisalabad, and Bahawalpur division. It should be done before the end of May on Pruning and intensity levels of enhance the vegetative growth and fruit quality of ber.

Keyword: Jujube; Production; Pruning intensities; Quality; Yield

\section{Introduction}

Jujube (Ziziphus mauritiana Lam.) is one of the ideal fruits in Pakistan. Its originated indo-Pak and china where its cultivation is older than 4000 years, It belongs to the family Rhamnaceae [1]. In Pakistan the successfully to cultivated in Hyderabad, Khairpure Lahore, Sargodha, Faisalabad and Bahawalpur, division in some region of KPK. In ancient times small size ber fruit cultivated, more than 35 ber verities exist in
Pakistan which have huge export potential and it export to Middle East countries [2] with the quality and sour taste now with advancement in research, in everywhere in Pakistan. It is commonly known as ber in Pakistan and is one of the most common fruit. It is an important fruit crop for arid and semi-arid regions in tropical and subtropical regions grow in Pakistan and other countries in central Asia. China and Taiwan. It is more associated with Pakistani 
and cultivated widely for its resistance to grow drought and other diversified soil and climatic conditions and suitability even under wasteland [3]. It is hardy tree that copes with extreme temperature and best thrives under rather dry condition. Fruit quality, is best under hot sunny and dry conditions, but there should be a rainy seasons to support grown and flowering, leaving enough soil moisture to carry the fruit to maturity. Commercial cultivated such as salinity, drought and water logging. In this view of the recent development in production technology of this crop, the cultivation of ber crop is becoming increasing popular in many parts of Pakistan. It is an ideal fruit tree for arid and semi-arid region of the country. The present work is an effort to view the present status of ber production and for future in Pakistan. While, in the warm areas of Punjab and Northern Sindh some are planted with an area of 2927 hectares having 16744 tons average yield in Pakistan [4]. It has also mention in worldwide most nutritious plants rich in $\mathrm{p}, \mathrm{k}$ and $\mathrm{Fe}$ [5]. Basically, Pruning is an art as well as science. Art because it requires skill and science because pruned has to have adequate knowledge and experience regarding the growth habit, flowering, and fruiting behavior for a particular species. During pruning operation, certain branches are cut completely or a portion of it is retained to improve plant shape and also to influence its growth, flowering and fruitfulness. Pruning is also essential to improve fruit quality and to repair injury. Sometime, it is difficult to distinguish training from pruning. The pruning aimed at giving a particular shape or form is referred as training. It determines the general character and even the details of plants and its branching patterns, whereas, pruning is meant to contribute more in determining trees role in fruiting. The annual pruning is necessary to maintain the plants in productive state and to reduce the quality fruits. In jujube, flowers fruits are borne on young shoots of currents seasons growth [6] and remain confined to its first and second order to branches i.e. the secondary and tertiary branches. Pruning should therefore, induce the emergence of maximum number of secondary's and tertiary in vigorous shoot. The annual pruning is therefore, essential to get maximum fruitful and vigorous shoots in ber. About $75 \%$ of fruits produced on any pruned branches are born on vigorous shoots, and only $5 \%$ on other shoots [7]. Pruning also opens up the tree form for sunlight, air and ease of chemical spraying. The works carried out by time of pruning on vegetative growth, yield and quality. Natural condition, ber has a bushy and spreading growth habit often with long strategy and weak crotches. A strong open and upright frame is required to be achieved by training to obtain highly yield of good quality fruits. This is done in the plants in the field or after budding. Under the subtropical condition of Pakistan, planting is done grow June August, and the plants are allowed to grow until the following spring (March- May) when it is headed back keeping 1-2 basal buds on the scion portion just above the graft union to induced development of vigorous shoots. One upright growing vigorous shoot is retained from the scion bud [8]. The trunk is kept clean up to a height of $30 \mathrm{~cm}$ from ground level removing all side shoots. Three- four properly species and favorably placed branches are allowed to grow form the main trunk. The top of the trunk is again headed back during March to encourage growth of side branches. Ber has character to produce branches usually starting from sixth or ninth node from the base and subsequently at regular intervals of three internodes. It is observed that during spring or summer seasons of the following year, shoots emerges from the basal buds of these second arise themselves either dry out or remain insignificant in growth and vigor in the spring of the second year, the second arise are again pruned to basal buds for emergence of vigorous shoots in the next season. On these main branches, 3-4 upright growing and well-spaced side 
shoots are remained and top of such branches are again removed in the spring of the fourth year, these side shoots are pruned. The time of pruning in ber is region specific. In subtropical regions, the most appropriate time for pruning is during hot and dry summer when plants shed off their leaves and inter inn dormancy, but it should be done before the onset of new growth. Under the adverse conditions like in arid region, plant does not put forth new growth unless some good rainfall is received. In tropical region with valid winter and rainfall during December - March and early onset of summer rainfall (e.g. Sukkur) Pakistan, pruning can be carried out at any time February to April with a possibility of regulating fruit maturity at desired time [9]. In tropical region with no winter rainfall (e.g. Hyderabad, Tandojam and Sukkur) it is advisable to prune ber trees during first fortnight of March which result in early flowering and thus early harvest of fruits, though the maximum fruit yield was recorded when, the pruning was done in second fortnight of March and Hyderabad in Sukkur, Sindh the best time of pruning is before, the end of May. The time of pruning influences bud sprouting and determine annual vegetative growth of plants and delayed bud sprouting due to delayed pruning with maximum shoot length, diameter, and leaf area by pruning half of the primary branches from base and remaining half to ( 15 buds) on $\left(25^{\text {th }}\right.$ March $)$ and the tree pruned on $10^{\text {th }}$ March produced the plants and maximum number of branches per tree. The annual shoot growth as well as leaf area was found maximum on tree pruned in ( $25^{\text {th }}$ March) The number of shoot and shoot length on trees pruned on $\left(15^{\text {th }}\right.$ March) were significantly higher as compared to $\left(15^{\text {th }}\right.$ April $)$ while shoot length diameter was at part on both of dated of pruning [10]. The found that early pruning started from ( $5^{\text {th }}$ May) to middle June resulted in increased main shoot length than succeeding treatment. The main shoot length was at par on all pruning dated till middle of March, whereas it was significantly lower on following dates, the annual shoot growth and leaf area was found maximum on the trees prune on $25^{\text {th }}$ May. Prune ber tree at $70 \mathrm{~cm}$ from base during last week of June and this resulted in better response in terms of shoot growth. The time of pruning in general has profound effect on bud sprouting. Flower initiation. Fruit setting, yield and quality of fruits. In arid regions of North West Sukkur, early pruning induces early flowering. The fruit yield is higher when prune is done during the month of March in flowering. Under the arid zone of Pakistan pruning done on $15^{\text {th }}$ April gave optimum performance in respect to $12^{\text {th }}$ April cultivars of ber Hyderabad, Sukkur, Khairpure, and Multan, Sargodha and Lahore district. However, total soluble solids and pulp contain of the fruits was highest when pruned on $20^{\text {th }}$ March [11]. The pruning of three years old Ziziphus mauritiana Lam. Tree of fortnightly intervals from (10 ${ }^{\text {th }}$ April to $\left.15^{\text {th }} \mathrm{July}\right)$ revealed that pruning dates had no significant effect on vegetative growth but early pruned trees flowered earlier by (15 days) in the earliest pruned trees fruit set was (highest 15.7\%) and trees pruned on $\left(\right.$ March $30^{\text {th }}$ ) and lowest on (July 15 ${ }^{\text {th }} 9.5 \%$ ) the fruit matured on (18 and $28^{\text {th }}$ April) When pruning during last week of (July at $65 \mathrm{~cm}$ ) from base resulted better response in terms of shoots growth and early pruning (First fortnight of March under Hyderabad and Tandojam conditions) advanced the date of flowering with minimum number of days required to flowering couple with earlier fruit maturity as compared to late pruned trees. Gola is working (2014), while working with time of pruning in ber also concluded that between (12-15 ${ }^{\text {th }}$ March) retaining (10 buds) for higher yield of better quality fruits.

\section{Materials and methods}

The present study was carried out to evaluate the "effect of pruning on fruits production of Jujube Research station at Tandojam. During successive seasons (2014) The Sindh Agriculture Tandojam 
Pakistan, on the (18 year) old ber trees of planted in rowed and stand spacing of $(3 \mathrm{~m}$ $\times 2 \mathrm{~m})$ on the Horizontal bed sloping eastwards. A total of jujube trees were observed on pruned at the same intensity, at i.e. ( $15^{\text {th }}$ May) with the following pruning, with the four replications. Hence there were total 20 plants. Four treatments were too applied. T1 (pruning on $20^{\text {th }}$ May) T2 (pruning on $25^{\text {th }}$ May) T3 (pruning on $15^{\text {th }}$ June) T4 (pruning on $25^{\text {th }}$ August to $25^{\text {th }}$ on September) and the fruit weight $(30.25 \mathrm{~g})$ the maximum fruit size $(32.40 \mathrm{~mm} 2)$ highest June) the maximum number of branch per tree (25 days to flowering. (65 days) blooming on $15^{\text {th }}$ sugar $(6.25 \%)$, and the maximum vitamin- $\mathrm{C}$ contents. Pruning in ber is required right from the year of planting. The experiment was design as Randomized Complete block design (RCBD). With this observation were taken on selected representative branches. The all flowers on the selected branches were counted and fruit. Pruning is necessary in Ziziphus to maintain productivity of the fruits trees and to improve the quality of fruit. Trees were subjected to the same cultural practices usually done.

\section{Experimental design and root pruning treatments}

The experiment involved these consisted of trees in the same row prior to prune buds break. Four treatments were applied to the examined tree on March 15, 2014.

1. The number of branch per tree was counted which sprouted after pruning.

2. Total blooming prior and days to flowering were calculated.

3. Five branches towards the east, west, north and south were selected.

4. Fruit size measured by the digital caliper fruits weight $g$ and was measured.

5. Acidity $\%$ was to determine the sample and vitamin-C was qualified as described removed root system at the primary buds. From trunk root system was cut with a sharp. Shade at different distances from the trunk on both rows of jujube trees.

\section{Statistical analysis}

The data collected from the subjected for statistical analysis using Statistix version 8.1 [12]. In order to know the various superiority, of treatments the least significant different (LSD) test 0.05 probability levels was performed.

\section{Results and discussion}

\section{Blooming period days}

The blooming period earlier started in ber tree when these early pruning was to done. Data in (Table 1) they showed that blooming from $22^{\text {th }}$ August and continued to $28^{\text {th }}$ October. But T2 blooming start i.e. from the $5^{\text {th }}$ September and they continue to $25^{\text {th }}$ October. T3 further, blooming was delayed i.e. the $10^{\text {th }}$ September to $20^{\text {th }}$ October and T4 thus delay in these treatments, from $18^{\text {th }}$ September to $25^{\text {th }}$ October and first the 4th pruning treatments $[13,14]$. In subtropical condition that reported the most timing for suitable pruning in this month of May. The blooming pruning done during the first and fortnight of May. When the tree their leaves and shed during this period, in early pruning in causes this flowering and fruits maturity. The ultimately finding line results and report [15]. Reported that the pruning during this May results in flowering in last week of August.

\section{Days of flowering}

The maximum flowering days 60.00 was recorded in the $\mathrm{T} 1$ and followed by $\mathrm{T} 2$ 50.00 was the flowering days T3 42.00 and T4 38.00 was similar results have reported that [16]. Recorded more than Number of flowering days and early in pruning was done May, the tree compared to prune at the end of June [17]. The result was significant when pruning in ber was done at these $15^{\text {th }}$ and $20^{\text {th }}$ July. In this ranges, the pruning early induces flowering in early it was also that more observed number of flowering is practiced in May.

\section{Number of branches per tree}

The data showed that the number of branches per tree highly effected with pruning. That can be seen the results that number of secondary and the branches per 
tree was the significant, high (22.00) in T1 and the pruning carried out in $\left(20^{\text {th }}\right.$ of May) followed T2 (18.00) was done on pruning $\left(25^{\text {th }}\right.$ May) The minimum number of the branches are 16.00 in T3 [18]. The results showed that was more branches in this tree pruned on $\left(22^{\text {th }}\right.$ May) The primary pruning in connected with the most suitable

Table 1. Blooming period, days to flowering and number of branches per tree after different Pruning treatments of ber

\begin{tabular}{|c|c|c|c|}
\hline Treatments & Total blooming period & Days to Flowering & $\begin{array}{c}\text { Number of branches } \\
\text { per Tree }\end{array}$ \\
\hline T1 (Pruning on $16^{\text {th }}$ May) & 22 August to $28^{\text {th }}$ October & 60.00 & 22.00 \\
\hline T2 (Pruning on $25^{\text {th }}$ May) & $\begin{array}{c}5^{\text {th }} \text { September to } 25^{\text {th }} \\
\text { October }\end{array}$ & 50.00 & 18.00 \\
\hline T3 (Pruning on $12^{\text {th }}$ June) & $\begin{array}{c}10^{\text {th }} \text { September to } 20^{\text {th }} \\
\text { October }\end{array}$ & 42.00 & 16.00 \\
\hline T4 (Pruning on $22^{\text {th }}$ June) & $\begin{array}{c}18^{\text {th }} \text { September to } 25^{\text {th }} \\
\text { October }\end{array}$ & 38.00 & 12.00 \\
\hline \multicolumn{2}{|r|}{ LSD 0.05 } & 760 & 272 \\
\hline
\end{tabular}

\section{Fruit weight $\mathrm{g}$}

The effect of pruning on fruits production on fruits weight of the single was examined and the results in this pruning fruit weight $g$ (31.45) recorded when the fruits harvest from tree on pruned on $20^{\text {th }}$ May while this the maximum fruits weight (27.08) recorded from this harvest in T3 (22.65) [20] was recorded that pruned in this effect of ber. While the minimum fruits weight (19.50) was recorded T4 from the tree was obtained last fortnight of June [21] and that pruning had significance on fruit weight of ber.

\section{Fruits size}

The results obtained that maximum fruits size (35.50) and tree harvest on pruned $12^{\text {th }}$ May, while the fruits minimum size (32.00) was recorded from the tree on (15 ${ }^{\text {th }}$ June). The results with finding the pruning on ber temperature and more number of branches are and the number of per tree branches to decrease in significant, when the pruning delay to (12 $2^{\text {th }}$ June) the buds recorded to sprouting was heavy concerned with pruning [19]. Was recorded that shoots was produced in pruning was also done.

Table 2. Fruits weight, fruits size, and highest sugar and vitamin $C$ contents on different Pruning treatment of ber

\begin{tabular}{|c|c|c|c|c|}
\hline Treatments & Fruits weight & Fruits Size & Highest Sugar & $\begin{array}{c}\text { Vitamin C } \\
\text { content }\end{array}$ \\
\hline T1 (Pruning on 16 & & 35.50 & 6.22 & 130.50 \\
\hline T2 (Pruning on $25^{\text {th }}$ May) & 31.45 & 32.00 & 5.00 & 122.30 \\
\hline T3 (Pruning on 12 ${ }^{\text {th }}$ June) & 22.08 & 30.70 & 4.00 & 120.65 \\
\hline T4 (Pruning on 22 ${ }^{\text {th }}$ June) & 19.50 & 28.65 & 3.85 & 115.00 \\
\hline LSD 0.05 & 402.72 & 507.4 & 76.28 & 1.953 \\
\hline
\end{tabular}




\section{Conclusion}

The yield of the ber fruits tree decreased with the increase in the intensity of the pruning. The fruit weight, fruits size, Highest, Sugar and the vitamin C contents was the obtained maximum trees prune at the $\left(15^{\text {th }}\right.$ May) is most suitable pruning time to maximum fruits yield and quality in ber.

\section{Authors' contributions}

Conceived and designed the experiments: AQ Gola \& MI Jakhro, Performed the experiments: AQ Gola \& AK Tareen, Analysis the data: AQ Gola, MS Mastoi, MA Khosa \& AK Tareen, Contributed material/ analysis / tools: MI Jakhro, Wrote the paper: AQ Gola.

\section{Reference}

1. Rhodes MJC (1995). The Physiological basis for the conservation, and research papers and reports, Second National Workshop on Arid Zone Fruit Research, Udaipur, (India) pp 242-243.

2. Sharif NJ, Jaskani M, Ishfaq MM, Abbas \& Memon NN (2013). Categorization of ber varieties in relation to blooming period, fruit setting and harvesting time. Pak J Agri Sci 50(3): 407-413.

3. Martinuzzo R (2006). Jujube (Ziziphus jujube) mill Rhamnaceae. A Tuscan farm house "the Jujube" Casa Vacanza "I1 Giuggiolo".

4. Anonymous (2003-2004). Fruit, vegetables and condiments statistics of Pakistan. Govt. of Pakistan, Finance Division, Economic Adviser's wing, (Islamabad) pp 1-2.

5. Boora RS \& Singh H (2008). Effect of pruning time and severity on yield and fruit quality in ber (Ziziphus mauritiana Lam.) cv. Sanaur-2. Harya pp 1-5.

6. Singh H, Bal JS \& Singh G (2000). Standardization of pruning technique in ber. Indian J of Hort 61(3): 259-260.

7. Kurian RM (2003). Studies on sylleptic ranches in Ziziphus spp. with special reference to productivity in ber (Ziziphus mauritiana Lam.) cv.
Umran. M.Sc. (Hort.) Thesis, University of Agriculture Science, Banglore (India).

8. Pareek OP (2001). Ber International Centre for Underutilized Crops, Southampton (UK) pp 292.

9. Vishal N (2001). Ber Coordinated Fruit Research in Indian Arid Zone-A Two Decades Profile (1976-1995). National Research Centre for Arid Horticulture, Bikaner (India) pp 30-90.

10. Rauf VU \& Diware DV (2005). Effect of pruning time and severity on growth and development of ber (Ziziphus mauritiana Lam.). J of Soils and Crops 15(1): 60-63.

11. Jawadagi R, Reddy BGM, Pattar PS \& Ganiger VM (2001). Response of ber cultivars to time of pruning under arid zones of Karnataka. Karnataka $J$ of Agric Sci 14(4): 1059-1062.

12. Statistix (2006). Analytical software. Statistix 8.1 user's manual. Analytical software, Tallahssee (Florida).

13. Gupta MR (2009). Physico-chemical characters of some promising ber cultivars grown at Bahadurgarh (Patiala). Punjab Horti J 12(3-4): 6064.

14. Kunda AHK, Wazir FK, Abdul G \& Wazir ZDK (2013). Morphological characteristics, yield and yield components of different cultivars of ber (Ziziphus jujuba Lam). Sarhad J of Agri 5(1): 53-57.

15. Pareek OP \& Nath V (2014). Ber Fruit Research in Indian Arid Zone -A two decades profile. National Research Centre for Arid Horti. Bikaner (India) pp 9-30.

16. Sandhu AS, Minhas PPS \& Grewal G (2001). Influence of time of pruning on growth flowering, fruit setting and fruit quality of Umran ber (Ziziphus mauritiana Lam.). Haryana J of Horti Sci 21(1-2): 1-5.

17. Sandhu SS, Thind SK \& Bal JS (2012). Effect of pre-harvest spray of ethephon on size, quality and ripening of ber 
(Ziziphus mauritiana Lam.) cv. Umran. Indian J Horti 46(1): 23-27.

18. Zandi K, Taherzadeh M, Yaghoubi R, Tajbakhsh S, Rastian \& Sartavi Z (2011). Antiviral activity of Avicennia marina against herpes simplex virus type 1 and vaccine strain of poliovirus. (An in vitro study). J of Med Plant Res 3(2): 771-775.

19. Raturi Z, Sandhu A \& Khan S (1993). Effect of pruning time on productivity and physico-chemical characters of ber (Ziziphus mauritiana Lam.) cv. Umran. $J$ of Res Punjab Agri Uni Ludhiana 21(4): 521-524.

20. Ploeg A, Smid GH \& Heuvelink E (2005). Cultivar difference in temperature demand of cut chrysanthemum. Act of Horti 6(11): 91-97.

21. Tuzel Y, Oztekin GB \& Gul A (2008). Recent developments in protected cultivation in Turkey. 2nd coordinating meeting of the regional FAO working group on greenhouse crop production in the SEE countries. 7-11. April (Antalya) pp 75-86.

22. Schmile V \& wski G (2008). The role of peat in assuring the quality of growing media Mires and Peat. Res $J$ 3(2): 1-8.

23. Regina R, Melton L \& Dufault RJ (2015). Nitrogen, phosphorus, and potassium fertility regimes affect tomato transplant growth. J of Hort Sci 26(2): 141-142.

24. Ozturka B, Bektasa E, Aglarb E, Karakayaa O \& Gun S (2018). Cracking and quality attributes of jujube fruits as affected by covering andpre-harvest Parka and $\mathrm{GA}_{3}$ treatments. Scientia Horticulturae 240(1): 65-71. 